\title{
Executive Dysfunction in Non-Psychotic Unipolar Depressed Patients: Assessement by the Wisconsin (Berg) Card Sorting Test
}

\author{
Marco Moniz ${ }^{1,2,3,4}$, Saul Neves de Jesus ${ }^{3,4}$, João Viseu ${ }^{3,4}$, Eduardo Gonçalves ${ }^{1}$, Susana Moreira ${ }^{1} \&$ Andreia \\ Pacheco ${ }^{1,5}$ \\ ${ }^{1}$ Department of Psychiatry and Mental Health, Hospital Center of Algarve, Faro, Portugal \\ ${ }^{2}$ António Silva Leal Foundation, Lisboa, Portugal \\ ${ }^{3}$ Faculty of Human and Social Sciences, University of Algarve, Faro, Portugal \\ ${ }^{4}$ Research Centre for Spatial and Organization Dynamics (CIEO), Faro, Portugal \\ ${ }^{5}$ Centre for Biomedical Research (CBMR), Faro, Portugal \\ Correspondence: Marco Moniz, Centro Hospitalar do Algarve, Departamento de Psiquiatria e Saúde Mental, Rua \\ Leão Penedo, 8000-386 Faro, Portugal. E-mail: emmoniz@gmail.com
}

Received: November 23, 2015

doi:10.5539/ijps.v8n1p112
Accepted: December 21, $2015 \quad$ Online Published: January 13, 2016

URL: http://dx.doi.org/10.5539/ijps.v8n1p112

\begin{abstract}
Introduction: Alterations in executive functioning are frequent in depressed subjects, being the Wisconsin Card Sorting Test (WCST) one of the most utilized instruments to assess it, even though, when individually compared, this test's items did not show consistency.

Method: This study aimed to compare the performance of a group comprising 36 non-psychotic unipolar depressed patients ( 23 women and 13 men, with a mean age of 44.28 years old $[S D=14.78]$ ) with 36 healthy controls ( 22 women and 14 men, with a mean age of 42.22 years old $[S D=15.19]$ ) in a computerized version of WCST.
\end{abstract}

Results: We found significant differences between depressed patients and healthy controls regarding number of categories, perseverative responses, perseverative errors, non-perseverative errors, percentage of conceptual level responses and failure to maintain set, clearly influenced by the variable age, which showed a shared variance between $17 \%$ and $33 \%$ in depressive patients' performance and between $16 \%$ and $26 \%$ in healthy controls' performance.

Conclusions: Results allowed us to identify differences in performance between the two groups, therefore this version of the WCST revealed itself a reliable alternative to assess Executive Functions (EFs), accessible to all clinicians.

Keywords: unipolar depression, Executive Functions (EFs), set-shifting, Wisconsin Card Sorting Test (WCST), normative data

\section{Introduction}

The Wisconsin Card Sorting Test (WCST) is one of the most currently used instruments in clinical practice to assess executive functioning. It is common its utilization to assess set-maintenance and set-shifting abilities, involved in the execution of prefrontal areas (Carrillo-de-la-Peña \& García-Larrea, 2007), more precisely dorsal regions of Prefrontal Cortex (PFC) (Zald \& Andreotti, 2010). Despite this fact, the main manuals of neuropsychology caution against using WCST results isolatedly as a marker of damage in the frontal lobe, hence recommending convergent measures of assessment (Lezak, Howieson, \& Loring, 2004; Strauss, Sherman, \& Spreen, 2006).

According to the Journal Citation Reports (JCR), over the last few years, the number of scientific publications has increased widely and journals that published ten or more papers on the WCST have a high impact factor (Silva-Filho, Pasian, \& Humberto, 2011). Clinical studies with Portuguese-speaking population have also increased, especially in Brazil, in particular focusing on clinical disorders such as obesity (Duchesne et al., 2010; Sousa \& Ribeiro, 2012), alcohol dependence (Salgado et al., 2009), substance dependence (Almeida, Flores, \& Scheffer, 2013; Matumoto \& Rossini, 2013), Alzheimer's disease (Hamdan \& Bueno, 2005), as well as on 
specific population, such as elderly (Beckert, Irigaray, \& Trentini, 2012; Wagner \& Trentini, 2009) and murderers (Del Pino \& Werlang, 2008).

Given that the WCST is an instrument that provides a large amount of statistical information, there are frequently questions about what measures are more important in order to assess the subject's performance, being the most utilized the result of perseverative errors, attempts to achieve the first category, and failure to maintain set (Strauss et al., 2006), as well as non-perseverative errors and number of achieved categories (Greve, Ingram, \& Bianchini, 1998; Greve, Bianchini, Hartley, \& Adams, 1999; Greve, Stickle, Love, Bianchini, \& Stanford, 2005).

Concerning its formats, over the last few years, various computerized versions of the WCST have emerged, either for application or scoring, partly due to the fact that recording and scoring errors are common in the paper version of the test. Clinically, results have been similar in manual and computerized versions (Fortuny \& Heaton, 1996).

Regarding depressed patients' performance in WCST, although healthy subjects do often achieve more categories than Major Depressive Disorder (MDD) patients (Wagner, Doering, Helmreich, Lieb, \& Tadić, 2012), results have not shown consistency over the past few years. Differences have appeared regarding only number of errors, non-perseverative errors and percentage of conceptual responses (Degl'Innocenti, Agren, \& Bäckman, 1998), number of categories and perseverative errors (Moritz et al., 2002), perseverative errors (Harvey et al., 2004), and, failure to maintain set and perseverative errors (Stordal et al., 2004).

Therefore, this study aimed to compare the performances of a sample of non-psychotic unipolar depressed patients with healthy controls, concerning the main psychometric markers in a computerized version of the WCST. One other objective of the current study was to present initial normative data of this version in order to enable its utilization in clinical contexts and in further investigation. This study is important because, on the one hand, it allowed to understand the cognitive functioning of unipolar depressed patients (without any influence of depressive disorders with manic and psychotic symptoms [e.g., bipolar and schizoaffective]), and, on the other hand, provided initial normative data so that clinicians across the world can use this instrument.

\section{Method}

\subsection{Participants}

Both studied samples, experimental and control groups, were comprised of 36 subjects each. The experimental (patients') group was composed of 23 women and 13 men, with a mean age of 44.28 years old $(S D=14.78)$ and a mean of $8.94(S D=3.54)$ years of education. The participants from this group were recruited in the city of Faro (Portugal), more precisely from the Department of Psychiatry and Mental Health of Hospital Center of Algarve (a state owned entity). With analogous characteristics, healthy controls comprised 22 women and 14 men, with a mean age of 42.22 years old $(S D=15.19)$ and a mean of $9.53(S D=3.68)$ years of education. Patients and controls did not differ significantly regarding gender $\left(\chi^{2}=.059, d f=1, p=.808\right)$, age $(t=.583, d f=70, p=.562$, $d=.137)$, and education $(t=-.978, d f=70, p=.331, d=-.163)$. All participants were Caucasians and Portuguese speakers.

\subsection{Measures}

A computerized version of the WCST (Mueller, 2013), from the Psychology Experiment Building Language (PEBL), a free access battery (Mueller \& Piper, 2014), described in greater detail elsewhere (Lyvers \& Tobias-Webb, 2010; Piper et al., 2012), was employed.

The same computer running Microsoft Windows 8.1 was used with all subjects, with a touch screen in order to minimize the difficulties of older subjects in using a mouse or a keyboard, and to attempt reproduce the manual version regarding the way of choosing the card.

We utilized a total number of 128 cards (i.e., two packs of 64 cards) and the principles were color, form or number, which changed every ten trials. After each trial, a feedback ("correct" or "incorrect") was displayed for 500 milliseconds (ms). Results obtained in each trial were provided by the software.

\subsection{Procedures}

All participants were assessed individually by a psychologist specifically certified for the purpose. Each participant completed a health and demographic questionnaire and depression diagnoses were confirmed through the MINI (Mini International Neuropsychiatric Interview) (Sheehan et al., 1997), the BSI (Brief Symptom Inventory) (Canavarro, 2007) and the Hamilton Depression Rating Scale for Depression (HAM-D-17-item) (Sousa, Lopes, \& Vieira, 1979). Exclusion criteria were current or prior history of bipolar disorders, schizophrenia, major psychosis, substance abuse, dementia and neurologic disease, including head injury 
involving a loss of consciousness. To discard malingering, Rey 15-Item Memory Test (15-IMT) was used (Simões et al., 2010).

This study was approved by the Hospital Center of Algarve Ethics Committee, in conformity with the Helsinki declaration. After being provided with all the information about the study, all participants signed an informed consent.

All analyzes were conducted using the Statistical Package for the Social Sciences (SPSS), version 20.0. The level of significance was set at $p<.05$.

\section{Results}

Results showed statistically significant differences between unipolar depressed patients and controls regarding number of achieved categories $(t=-2.911, d f=64.6, p=.005, d=-.692)$, perseverative responses $(t=2.408, d f=$ $70, p=.019, d=.568)$, perseverative errors $(t=3.303, d f=70, p=.002, d=.778)$, non-perseverative errors $(t=$ $2.555, d f=70, p=.013, d=.602)$, percentage of conceptual level responses $(t=-3.518, d f=70, p=.001, d=$ -.829), and failure to maintain set $(t=2.108, d f=57.9, p=.039, d=.505)$.

Depressed patients showed a higher mean in trials to achieve the first category $(M=26.25, S D=24.70)$ compared to healthy controls $(M=18.08, S D=12.94)$, however, that difference was not statistically significant $(p=.085)($ Table 1$)$.

Table 1. Descriptive statistics $(N=72)$

\begin{tabular}{|c|c|c|c|c|c|c|}
\hline & Depression $^{\mathrm{a}}$ & Healthy $^{b}$ & \multirow[b]{2}{*}{$t$} & \multirow[b]{2}{*}{$d f$} & \multirow[b]{2}{*}{$p$} & \multirow[b]{2}{*}{$d$} \\
\hline & $M(S D)$ & $M(S D)$ & & & & \\
\hline $\begin{array}{l}\text { Number of categories } \\
\text { achieved }\end{array}$ & $4.41(1.74)$ & $5.47(1.29)$ & -2.911 & 64.6 & .005 & -.692 \\
\hline Perseverative responses & $49.36(15.59)$ & $41.66(11.14)$ & 2.408 & 70 & .019 & .568 \\
\hline Perseverative errors & $20.13(12.39)$ & $11.55(9.45)$ & 3.303 & 70 & .002 & .778 \\
\hline Non-perseverative errors & $16.03(11.02)$ & $10.01(8.84)$ & 2.555 & 70 & .013 & .602 \\
\hline $\begin{array}{l}\text { \% Conceptual level } \\
\text { responses }\end{array}$ & $55.69(19.37)$ & $71.49(18.73)$ & -3.518 & 70 & .001 & -.829 \\
\hline $\begin{array}{l}\text { Trials to achieve } 1 \text { st } \\
\text { category }\end{array}$ & $26.25(24.70)$ & $18.08(12.94)$ & 1.757 & 52.8 & .085 & .414 \\
\hline Failure to maintain set & $1.36(1.41)$ & $.77(.86)$ & 2.108 & 57.9 & .039 & .505 \\
\hline
\end{tabular}

Healthy controls exhibited a strong negative correlation between the demographic variable age and number of achieved categories $(r(36)=-.519, p=.001)$ and percentage of conceptual level responses $(r(36)=-.487, p$ $=.003)$, as well as a strong positive correlation regarding perseverative errors $(r(36)=.469, p=.004)$, trials to achieve the first category $(r(36)=.482, p=.003)$, and failure to maintain set $(r(36)=.401, p=.015)$ (Table 2).

Table 2. Correlations and shared variances between WCST scores and age

\begin{tabular}{|c|c|c|c|c|}
\hline & \multicolumn{2}{|c|}{ Depression $^{\mathrm{a}}$} & \multicolumn{2}{|c|}{ Healthy $^{b}$} \\
\hline & $r$ & $r^{2}$ & $r$ & $r^{2}$ \\
\hline Number of categories achieved & $-.418^{*}$ & $.175^{*}$ & $-.519^{* *}$ & $.269^{* *}$ \\
\hline Perseverative errors & $.582^{* *}$ & $.338^{* *}$ & $.469^{* *}$ & $.220^{* *}$ \\
\hline$\%$ Conceptual level responses & $-.531^{* *}$ & $.282^{* *}$ & $-.487^{* *}$ & $.238^{* *}$ \\
\hline Trials to achieve 1 st category & .052 & .003 & $.482^{* *}$ & $.233^{* *}$ \\
\hline Failure to maintain set & .101 & .010 & $.401^{*}$ & $.161^{*}$ \\
\hline
\end{tabular}

Note. ${ }^{\mathrm{a}} n=36,{ }^{\mathrm{b}} n=36,{ }^{*} \mathrm{p} \leq .05,{ }^{* *} \mathrm{p} \leq .01$ 
Similar results were observed in the unipolar depressed patients' group, showing a strong negative correlation between age and number of achieved categories $(r(36)=-.418, p=.011)$ and percentage of conceptual level responses $(r(36)=-.531, p=.001)$, and a strong positive correlation regarding perseverative errors $(r(36)=.582$, $p=.001)$.

The variable age also maintained a high shared variance in healthy controls with regard to number of achieved categories $\left(R^{2}=.269, F(1,34)=12.54, p=.001\right)$, perseverative errors $\left(R^{2}=.220, F(1,34)=9.58, p=.004\right)$, percentage of conceptual level responses $\left(R^{2}=.238, F(1,34)=10.59, p=.003\right)$, trials to achieve the first category $\left(R^{2}=.233, F(1,34)=10.31, p=.003\right)$, and failure to maintain $\operatorname{set}\left(R^{2}=.161, F(1,34)=6.51, p=.015\right)$.

In the patients' group, however less significant, a shared variance between age and number of achieved categories $\left(R^{2}=.175, F(1,34)=7.21, p=.011\right)$, perseverative errors $\left(R^{2}=.338, F(1,34)=17.39, p=.001\right)$, and percentage of conceptual level responses $\left(R^{2}=.282, F(1,34)=13.34, p=.001\right)$ was evident.

\section{Discussion}

We performed a student's $t$-test to compare the current study's results to those obtained by a similar one that used a computerized version of WCST as well (Merriam, Thase, Haas, Keshavan, \& Sweeney, 1999) (Table 3) and found no significant differences, except for percentage of conceptual level responses in patients' group $(t=2.260$, $d f=113, p=.025, d=-.454)$ and trials to achieve the first category in healthy controls $(t=2.341, d f=95, p$ $=.021, d=.446)$.

Table 3. Comparison of the current study's results to Merriam et al.'s (1999) $(N=212)$

\begin{tabular}{|c|c|c|c|c|c|c|}
\hline & \multicolumn{2}{|c|}{ Depression } & \multirow[b]{3}{*}{$t$} & \multirow[b]{3}{*}{$d f$} & \multirow[b]{3}{*}{$p$} & \multirow[b]{3}{*}{$d$} \\
\hline & Current Study ${ }^{a}$ & Merriam (1999) ${ }^{b}$ & & & & \\
\hline & $M(S D)$ & $\mathrm{M}(S D)$ & & & & \\
\hline Age (years) & $44.28(14.78)$ & $35.49(8.12)$ & 4.109 & 113 & .001 & .738 \\
\hline HDSD - 17-item & $20.44(7.40)$ & $16.79(6.11)$ & 2.776 & 113 & .006 & .537 \\
\hline $\begin{array}{l}\text { Number of categories } \\
\text { achieved }\end{array}$ & $4.41(1.74)$ & $5.00(1.53)$ & 1.836 & 113 & .069 & -.360 \\
\hline Perseverative errors & $20.13(12.39)$ & $17.57(12.42)$ & 1.025 & 113 & .307 & .206 \\
\hline $\begin{array}{l}\% \text { Conceptual level } \\
\text { responses }\end{array}$ & $55.69(19.37)$ & $64.42(19.06)$ & 2.260 & 113 & .025 & -.454 \\
\hline $\begin{array}{l}\text { Trials to achieve } 1 \text { st } \\
\text { category }\end{array}$ & $26.25(24.70)$ & $18.84(16.83)$ & 1.879 & 113 & .062 & .350 \\
\hline \multirow[t]{4}{*}{ Failure to maintain set } & $1.36(1.41)$ & $1.08(1.27)$ & 1.058 & 113 & .291 & .208 \\
\hline & \multicolumn{2}{|c|}{ Healthy } & & & & \\
\hline & Current Study $^{c}$ & Merriam (1999) $^{d}$ & & & & \\
\hline & $M(S D)$ & $M(S D)$ & $t$ & $d f$ & $p$ & $d$ \\
\hline Age (years) & $42.22(15.12)$ & $26.08(7.67)$ & 6.970 & 95 & .001 & 1.346 \\
\hline $\begin{array}{l}\text { Number of categories } \\
\text { achieved }\end{array}$ & $5.47(1.29)$ & $5.65(1.02)$ & .759 & 95 & .449 & -.154 \\
\hline Perseverative errors & $11.55(9.45)$ & $10.26(7.05)$ & .765 & 95 & .445 & .154 \\
\hline $\begin{array}{l}\% \text { Conceptual level } \\
\text { responses }\end{array}$ & $71.49(18.73)$ & $74.31(13.90)$ & .855 & 95 & .394 & -.170 \\
\hline $\begin{array}{l}\text { Trials to achieve } 1 \text { st } \\
\text { category }\end{array}$ & $18.08(12.94)$ & $13.61(5.74)$ & 2.341 & 95 & .021 & .446 \\
\hline Failure to maintain set & $.77(.86)$ & $.75(1.15)$ & .090 & 95 & .928 & .019 \\
\hline
\end{tabular}

Note. ${ }^{\mathrm{a}} n=36,{ }^{\mathrm{b}} n=79,{ }^{\mathrm{c}} n=36,{ }^{\mathrm{d}} n=61$ 
These differences may be due to mean difference in age between studies $(p=.001)$, having this variable a percentage of variance of $28 \%$ in unipolar depressed patients regarding percentage of conceptual level responses and of $23 \%$ in healthy controls concerning trials to achieve the first category.

As far as depressed subjects' performance is concerned, the current study focused only on non-psychotic unipolar depressed patients and therefore it was possible to find differences in perseverative errors, categories, failure to maintain set and percentage of conceptual level responses - the test's main neuropsychological markers (set-shifting, set-failure and insight) — enabling us to validate individually results obtained by previous studies (Degl'Innocenti et al., 1998; Harvey et al., 2004; Moritz et al., 2002; Stordal et al., 2004).

This study's main limitation was the size of the sample concerning both patients and healthy controls, which prevented us from validating clearly normative data of this test. Future research comparing wider numbers of subjects is therefore recommended.

Since this is an instrument not covered by copyright law, we can hypothesize the sampling being hereafter carried out not by a clinician individually, but more consistently by several psychologists, which might allow the increase of the reference sample size.

In order to share these initial data, we present a percentile table of the present sample (Table 4).

Table 4. Percentile of healthy and depressed subjects

\begin{tabular}{|c|c|c|c|c|c|c|c|c|c|c|}
\hline & \multicolumn{5}{|c|}{ Depression $^{\text {a }}$} & \multicolumn{5}{|c|}{ Healthy $^{\mathrm{b}}$} \\
\hline & 10 & 25 & 50 & 75 & 90 & 10 & 25 & 50 & 75 & 90 \\
\hline Number of categories completed & 1 & 3 & 5 & 6 & 6 & 2.7 & 6 & 6 & 6 & 6 \\
\hline Perseverative errors & 36 & 29.5 & 17 & 10.2 & 6.7 & 25.6 & 17.7 & 7 & 5 & 4 \\
\hline$\%$ Conceptual level responses & 23.4 & 42.1 & 57.0 & 65.9 & 83.1 & 34.9 & 59.4 & 79.1 & 86.9 & 88.2 \\
\hline Trials to achieve 1 st category & 69.5 & 31 & 14 & 11 & 10 & 35.5 & 20.7 & 13 & 11 & 10 \\
\hline Failure to maintain set & 3.3 & 2 & 1 & 0 & 0 & 2 & 1 & 1 & 0 & 0 \\
\hline
\end{tabular}

Note. ${ }^{\mathrm{a}} n=36,{ }^{\mathrm{b}} n=36$

\section{Acknowledgments}

We thank all participants of this study.

\section{References}

Almeida, R. M. M., Flores, A. C. S., \& Scheffer, M. (2013). Ideação suicida, resolução de problemas, expressão de raiva e impulsividade em dependentes de substâncias psicoativas. Psicologia: Reflexão e Crítica, 26, 1-9. http://dx.doi.org/10.1590/S0102-79722013000100001

Beckert, M., Irigaray, T. Q., \& Trentini, C. M. (2012). Qualidade de vida, cognição e desempenho nas funções

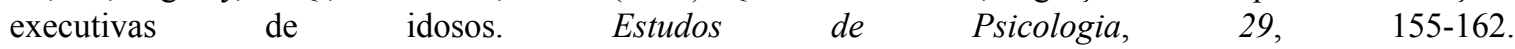
http://dx.doi.org/10.1590/S0103-166X2012000200001

Canavarro, M. C. (2007). Inventário de Sintomas Psicopatológicos (BSI): Uma revisão crítica dos estudos realizados em Portugal. In M. R. Simões, C. Machado, M. M. Gonçalves, \& L. S. Almeida (Eds.), Avaliação psicológica: Instrumentos validados para a população portuguesa (Vol. III, pp. 305-330). Coimbra, Portugal: Quarteto Editora.

Carrillo-de-la-Peña, M. T., \& García-Larrea, L. (2007). Right frontal event related EEG coherence (ERCoh) differentiates good from bad performers of the Wisconsin Card Sorting Test (WCST). Neurophysiologie Clinique/Clinical Neurophysiology, 37, 63-75. http://dx.doi.org/10.1016/j.neucli.2007.02.002

Degl'Innocenti, A., Agren, H., \& Bäckman, L. (1998). Executive deficits in major depression. Acta Psychiatrica Scandinavica, 97, 182-188. http://dx.doi.org/10.1111/j.1600-0447.1998.tb09985.x

Del Pino, V., \& Werlang, B. S. G. (2008). Flexibilidade mental na resolução de problemas em indivíduos que cumprem pena por homicídio qualificado. Psicologia: Reflexão e Crítica, 21, 142-150. http://dx.doi.org/10.1590/S0102-79722008000100018

Duchesne, M., Mattos, P., Appolinário, J. C., Freitas, S. R., Coutinho, G., Santos, C., \& Coutinho, W. (2010). 
Assessment of executive functions in obese individuals with binge eating disorder. Revista Brasileira de Psiquiatria, 32, 381-388. http://dx.doi.org/10.1590/S1516-44462010000400011

Fortuny, L. I. A., \& Heaton, R. K. (1996). Standard versus computerized administration of the wisconsin card sorting test. The Clinical Neuropsychologist, 10, 419-424. http://dx.doi.org/10.1080/13854049608406702

Greve, K., Bianchini, K. J., Hartley, S. M., \& Adams, D. (1999). The Wisconsin Card Sorting Test in stroke rehabilitation factor structure and relationship to outcome. Archives of Clinical Neuropsychology, 14, 497-509. http://dx.doi.org/10.1016/S0887-6177(98)00045-6

Greve, K. W., Ingram, F., \& Bianchini, K. J. (1998). Latent structure of the Wisconsin Card Sorting Test in a clinical sample. Archives of Clinical Neuropsychology, 13, 597-609. http://dx.doi.org/10.1016/S0887-6177(97)00075-9

Greve, K. W., Stickle, T. R., Love, J. M., Bianchini, K. J., \& Stanford, M. S. (2005). Latent structure of the Wisconsin Card Sorting Test: A confirmatory factor analytic study. Archives of Clinical Neuropsychology, 20, 355-364. http://dx.doi.org/10.1016/j.acn.2004.09.004

Hamdan, A. C., \& Bueno, O. F. A. (2005). Relações entre controle executivo e memória episódica verbal no comprometimento cognitivo leve e na demência tipo Alzheimer. Estudos de Psicologia, 10, 63-71. http://dx.doi.org/10.1590/S1413-294X2005000100008

Harvey, P. O., Le Bastard, G., Pochon, J. B., Levy, R., Allilaire, J. F., Dubois, B., \& Fossati, P. (2004). Executive functions and updating of the contents of working memory in unipolar depression. Journal of Psychiatric Research, 38, 567-576. http://dx.doi.org/10.1016/j.jpsychires.2004.03.003

Lezak, M. D., Howieson, D. B., \& Loring, D. W. (2004). Neuropsychological assessment (4th ed.). Oxford, UK: Oxford University Press.

Lyvers, M., \& Tobias-Webb, J. (2010). Effects of acute alcohol consumption on executive cognitive functioning in naturalistic settings. Addictive Behaviors, 35, 1021-1028. http://dx.doi.org/10.1016/j.addbeh.2010.06.022

Matumoto, P. A., \& Rossini, J. C. (2013). Avaliação das funções atentivas e flexibilidade mental em dependentes químicos. Psicologia: Reflexão $e$ Crítica, 26, 339-345. http://dx.doi.org/10.1590/S0102-79722013000200014

Merriam, E. P., Thase, M. E., Haas, G. L., Keshavan, M. S., \& Sweeney, J. A. (1999). Prefrontal cortical dysfunction in depression determined by Wisconsin Card Sorting Test performance. The American Journal of Psychiatry, 156, 780-782.

Moritz, S., Birkner, C., Kloss, M., Jahn, H., Hand, I., Haasen, C., \& Krausz, M. (2002). Executive functioning in obsessive-compulsive disorder, unipolar depression, and schizophrenia. Archives of Clinical Neuropsychology, 17, 477-483. http://dx.doi.org/10.1093/arclin/17.5.477

Mueller, S. T. (2013). The Psychology Experiment Building Language (Version 0.13) [Software]. Retrieved from $\mathrm{http}: / /$ pebl.sourceforge.net

Mueller, S. T., \& Piper, B. J. (2014). The Psychology Experiment Building Language (PEBL) and PEBL Test Battery. Journal of Neuroscience Methods, 222, 250-259. http://dx.doi.org/10.1016/j.jneumeth.2013.10.024

Piper, B. J., Li, V., Eiwaz, M. A., Kobel, Y. V., Benice, T. S., Chu, A. M., ... Raber, J. (2012). Executive function on the Psychology Experiment Building Language tests. Behavior Research Methods, 44, 124-124. http://dx.doi.org/10.3758/s13428-011-0096-6

Salgado, J. V., Malloy-Diniz, L. F., Campos, V. R., Abrantes, S. S. C., Fuentes, D., Bechara, A., \& Correa, H. (2009). Neuropsychological assessment of impulsive behavior in abstinent alcohol-dependent subjects. Revista Brasileira de Psiquiatria, 31, 4-9. http://dx.doi.org/10.1590/S1516-44462009000100003

Sheehan, D. V., Lecrubier, Y., Sheehan, K. H., Janavs, J., Weiller, E., Keskiner, A., ... Dunbar, G. C. (1997). The validity of the Mini International Neuropsychiatric Interview (MINI) according to the SCID-P and its reliability. European Psychiatry, 12, 232-241. http://dx.doi.org/10.1016/S0924-9338(97)83297-X

Silva-Filho, J. H., Pasian, S. R., \& Humberto, J. S. M. (2011). Teste Wisconsin de classificação de cartas: Uma revisão sistemática de 1952 a 2009. Psico-USF, 16, 107-116. http://dx.doi.org/10.1590/S1413-82712011000100012

Simões, M., Sousa, L., Duarte, P., Firmino, H., Pinho, M. S., Gaspar, N., ... \& França, S. (2010). Avaliação da simulação ou esforço insuficiente com o Rey 15-Item Memory Test (15-IMT): Estudos de validação em 
grupos de adultos idosos. Análise Psicológica, 28, 209-226. http://dx.doi.org/10.14417/ap.269

Sousa, M. P., Lopes, J. S., \& Vieira, R. (1979). Comparação entre a Escala de Hamilton e o Questionário de Beck na quantificacão das depressões. Jornal Do Médico, 103, 561-571.

Sousa, S., \& Ribeiro, O. (2012). Funções executivas em sujeitos candidatos e submetidos a cirurgia bariátrica. Psicologia, Saúde \& Doenças, 13, 389-398.

Stordal, K. I., Lundervold, A. J., Egeland, J., Mykletun, A., Asbjørnsen, A., Landrø, N. I., ... Lund, A. (2004). Impairment across executive functions in recurrent major depression. Nordic Journal of Psychiatry, 58, 41-47. http://dx.doi.org/10.1080/08039480310000789

Strauss, E., Sherman, E. M. S., \& Spreen, O. (2006). A compendium of neuropsychological tests: Administration, norms, and commentary (3rd ed.). Oxford, UK: Oxford University Press.

Wagner, G., \& Trentini, C. (2009). Assessing executive functions in older adults: A comparison between the manual and the computer-based versions of the Wisconsin Card Sorting Test. Psychology and Neuroscience, 2, 195-198. http://dx.doi.org/10.3922/j.psns.2009.2.011

Wagner, S., Doering, B., Helmreich, I., Lieb, K., \& Tadić, A. (2012). A meta-analysis of executive dysfunctions in unipolar major depressive disorder without psychotic symptoms and their changes during antidepressant $\begin{array}{lllll}\text { treatment. Acta } & \text { Psychiatrica } & \text { Scandinavica, } & 125, & \text { 281-292. }\end{array}$ http://dx.doi.org/10.1111/j.1600-0447.2011.01762.x

Zald, D. H., \& Andreotti, C. (2010). Neuropsychological assessment of the orbital and ventromedial prefrontal cortex. Neuropsychologia, 48, 3377-3391. http://dx.doi.org/10.1016/j.neuropsychologia.2010.08.012

\section{Copyrights}

Copyright for this article is retained by the author(s), with first publication rights granted to the journal.

This is an open-access article distributed under the terms and conditions of the Creative Commons Attribution license (http://creativecommons.org/licenses/by/3.0/). 